\title{
New voices in the debate: The Quesnel Women's Resource Centre and sustainable community development
}

\author{
by Greg Halseth ${ }^{1}$ and Jenny Lo ${ }^{2}$
}

To increase local diversity, and to enhance prospects of sustainability, two very distinct challenges must be addressed. First, attention must be given to local capacity building so that people and places can react to the challenges and opportunities encapsulated within processes of "change" or "adjustment." Second, there must be a wider participation in the sustainable development process and debate - after all, we cannot call it "community development" if the broader community does not participate. This paper provides an illustration of how one community group in small town British Columbia is working to address both the capacity building and participation challenges.

Key words: community capacity building, diverse participation, women

\section{Introduction}

The concept of sustainable development is increasingly commonplace within industry, environmental, and community development debates. The concept is, unfortunately, often used in very different ways within these varied forums and debates. In this paper, the concern is with the human and social capacity of places, and with the inclusion of alternative voices in local debates. We make the argument that to increase local diversity and to enhance prospects of sustainability, two very distinct challenges must be addressed. First, there must be attention given to local capacity building so that people and places can react to the pressures and opportunities arising from processes of "change" or "adjustment." Second, there must be a wider participation in local sustainable development processes and debates. If we are going to call it "community" development, then the broad community must be involved and people must feel they have a stake in the process and its outcome.

This paper provides an illustration of how one community group in small town British Columbia is working to address both the capacity building and participation challenges of sustainable community development. In the highly gender-segregated social and economic landscapes of British Columbia's resource-based communities, local community development organizations are becoming increasingly active in efforts to empower residents, regain some local control of economic decision making, maintain more of the revenues from economic

\footnotetext{
${ }^{1}$ Geography Program, University of Northern British Columbia, Prince George, British Columbia V2N 4Z9. E-mail: halseth@unbc.ca

${ }^{2}$ Geography Program, University of Northern British Columbia, Prince George, British Columbia V2N 4Z9. E-mail: loj@unbc.ca
}

Afin d'accroître la diversité locale, et pour améliorer les perspectives de durabilité, deux défis très différents doivent être relevés. Premièrement, il faut porter attention à la capacité de croissance locale de telle sorte que les gens et les groupes puissent réagir face aux défis et aux opportunités insérés dans les processus de « changement » ou «d'ajustement ». Deuxièmement, il doit y avoir une participation plus étendue dans le processus et le débat entourant le développement durable ( après tout, nous ne pouvons pas appeler cela « développement communautaire » si la majeure partie de la communauté ne participe pas. Cet article expose comment un groupe communautaire d'une petite ville de ColombieBritannique œuvre pour faire face à la capacité de croissance et aux défis reliés à la participation.

Mots-clés: capacité de croissance communautaire, participation diversifiée, femmes production within the community, and look at ways of directing local efforts to resolving issues such as community health and sustainable development. The Quesnel Women's Resource Centre provides a specific example of the ways in which women's activities foster community development in resourcebased towns.

\section{Sustainable Community Development}

It is perhaps appropriate that no single definition of sustainable community development has emerged, given that most understand this to be a locally driven, "grassroots" process (Galaway and Hudson 1994, Perry and Lewis 1994, Mitchell and Dahms 1997). It is especially appropriate given that both the central terms of "community" and "sustainability" are complex.

To begin, it is important to understand that the central term of "community" has been employed at times in ways which are exclusionary with respect to membership. A number of feminist writers have highlighted this process across a range of social and geographic contexts and debates (McDowell 1983, Mazey and Lee 1984, Bondi 1990, Kay 1991, Pratt and Hanson 1991, Mackenzie 1992, Anderson et al. 1994, Dominelli 1995). In the specific context of forestry dependant resourcebased communities, Reed (1997) argues that narrow interpretations of both economic sector participation and concepts such as social sustainability have marginalised women's participation in economic transition planning processes (see also Heald 1991). The general issue of marginalisation from economic participation is heightened within the social landscape of small resource-based communities.

In an effort to counter the lack of flexibility in some definitions of communities, in this paper we understand community as a set of relationships and relational processes which are self- 
defined by people as a reflection of their local interactions and participation. Understanding community in this way opens us to exploring how socially distinct groups both identify themselves and function within localities (Halseth 1993, Bryant 1995). Specifically, it allows us to question women's participation in ways which they define, and which they feel contributes to sustainable local development.

As with the concept of community, there are broad and diverse interpretations of the concept of sustainability. Beginning with an overt linkage to the capacity of natural eco-systems to cope with human demands, the concept has been broadened significantly to include the social and economic sustainability of human communities (Pearce et al. 1990). Pierce (1992) traces the genesis of our current debates over sustainability to the traditions of conservation. He identifies a clear connection to the rethinking of our use of both the environment and its natural resources wealth for human sustenance. Building upon a similar foundation, Reed and Slaymaker (1993) further describe sustainability as involving the capacity of a system to endure and to respond to change.

Clearly drawing out the human element, Beckley (1998) links to the Bruntland Commission's understanding of sustainable communities. In Our Common Future (World Commission 1987), the Bruntland Commission envisioned sustainable development as that which meets the needs of the present without compromising the ability of future generations to meet their own needs. It contains two key concepts: that of "needs," in particular the essential needs of the world's poor, and the idea of institutional limitations imposed on the environment's ability to meet present and future needs. From this, Beckley (1998, p.35) goes on to identify sustainable communities as involving the "institutions, social and physical infrastructure in a given place, that enables humans to meet their own needs and aspirations while not compromising those of future generations."

Similarly, Bauen et al. (1996, p.4) suggest that sustainability refers to the "long-term economic, environmental, and community health." They recognize that this concept has both broad scope and tremendous usefulness for community development. Its usefulness is relayed through two specific issues:

1) It introduces consideration of the long-term consequences from today's actions and decisions. This changing of the temporal framework is very different from standard economic modelling.

2) It also encourages practitioners to think broadly across issues, disciplines, physical and social boundaries - to search out new and creative solutions to meeting local needs.

Maser (1997) tries to integrate the concept of sustainability with the actions of local economic development. As suggested above, the concept of sustainability links very clearly with the carrying capacity of a local eco-system. Among the challenges Maser identifies for incorporating sustainability concepts into practice is the need to "re-invest" in both the local eco-system and local human capacity. In terms of local community development, Maser sees this as a very democratic process, one which incorporates senses of belonging, shared learning, and collective service. In order for local community development to be democratic, it must be accessible to, and implemented by, the majority of the population. Naturally, the more diverse the local population, the more difficulty in generating participation and consensus that will be encountered.
However, the net result will be an "empowerment" of local people. For Maser, social and environmental sustainability can only be derived from "bottom-up" community development. Participation at the local level is the critical element (Shaffer and Summers 1989, Cofsky and Bryant 1994).

Two recent volumes on rural employment and sustainability issues demonstrate the continuing difficulties encountered in conceptualizing women's participation in CED. A collection of essays on sustainable rural communities includes a special section of four papers on "Gender, Power, and the Family Farm" (Bryden 1994). While these chapters raise interesting approaches to, and illustrations of, the integration of women into rural economies, their separation out into a single section perpetuates the notion of uniqueness and difference. The danger in this is that as long as it can be categorized and separated-out, the participation of women does not need to be incorporated into all thinking on the topic. A larger international collection of papers on rural employment contains only one contribution which specifically draws out female participation. In that case, a household-based approach to alternative rural employment options is examined and the contributions of women in non-paid work are specifically drawn out (Bollman and Bryden 1997). In both of these examples, the role of women in rural economies is not conceptualized broadly or pervasively. Rather it remains highly isolated and individuated. The role of female contributions to the social and economic fabric of the community continues to be marginalised.

Lastly, we must recognize that sustainable community development is an inherently geographic phenomenon. Place and scale are critical. While various strategies and tools have been applied in urban and rural places, and at global, regional, and intimately local scales, there is no single formula to remedy a community's ills. The uniqueness of each place precludes this.

\section{Canadian Resource Communities}

While geographic diversity means there will be no universal solutions to sustainable community development, resourcedependent small towns across Canada do face relatively similar challenges. These towns are often very much "places on the periphery" in terms of both economic and political decision-making. For example, decisions to close mills are generally not made locally, and international trade agreements, personal and resource taxation policies, and even the allocation of the resource base itself, are not at present determined within resource hinterland regions. In northern British Columbia, local government representatives have tried many different ways through which to get provincial governments to pay attention and listen to their needs. Processes of marginalisation and powerlessness are not unknown.

For northern places, there are often a limited range of economic opportunities. This creates concerns about vulnerability and community sustainability. As well, small community size implies limited human resources and social infrastructure, while remote location often means limited access to alternative sources of information. In terms of advantages, however, local information networks in small town communities are generally well developed. People know one another. As well, many places have direct experience pulling together collectively to face some challenge or obstacle.

Some sustainable community development challenges and opportunities for northern small towns are clear. The gener- 

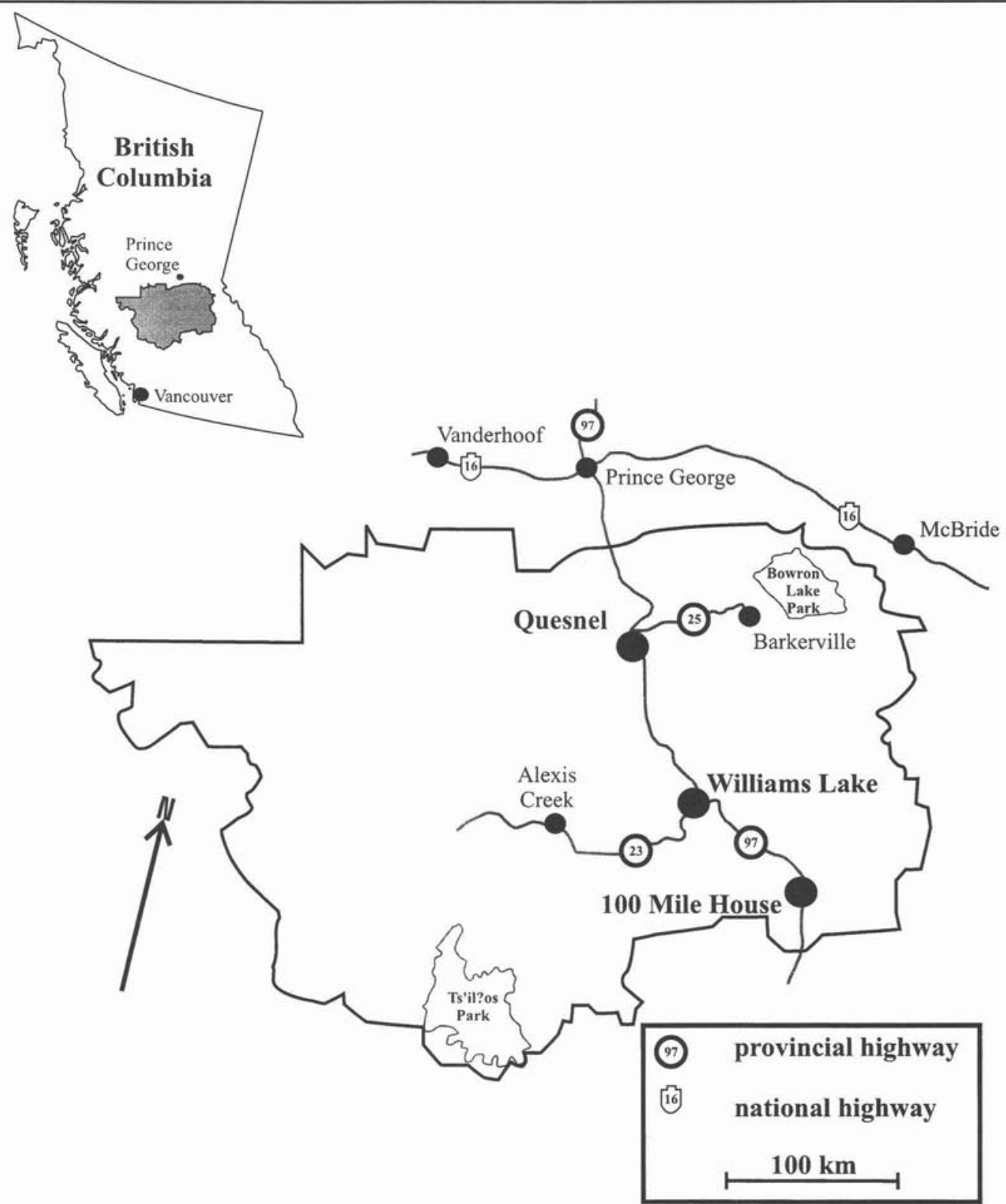

Fig. 1. Map of Case Study Location.

al educational and skills capacity of residents must be increased to permit the flexibility needed to respond to the rapidly changing global economy. As well, the local economic base must become more diversified. Dependence on a singleresource industry, whose profits go out of the town, will continue to leave many northern communities vulnerable to market cycles. The "infrastructure" which supports both the local economy and community development must be improved. Beyond human capacity issues, there is the historic communications technology of roads and railways, and there is also the new communications technology of electronic networks and Internet access.

Essential to local sustainable development is the need to include a broader range of voices from within the community. The par- ticipation of women in resource-based communities has traditionally been limited by the embedded hierarchical and paternalistic nature of these communities. A significant social aspect of resource-based towns is the way male-dominated primary industries have traditionally provided for the economic needs of the whole community. Employment in mining, logging, oil drilling and other natural resource extraction activities have traditionally employed male labourers in low-skill, high-wage jobs (Hak 1989, Marchak 1989). Even today, there continues to be a great disparity between male and female employees in resource-industry employment. Opportunities for women in resource-based communities are usually in lower paid service sector jobs such as waitressing, clerical work, and retail sales (Marchak 1983). Aside from gender- 
selective employment opportunities, there is a lack of infrastructure in resource-based communities to support the needs of women. This is especially true in terms of available and affordable child care, where a lack of opportunity leaves women economically disadvantaged, restricts women to their "traditional" role as nurturer with domestic responsibilities, and does not take into account the new realities of changing family structure. In this environment, sustainable community initiatives must first identify the fundamental needs and concerns of women in these communities.

\section{Case Study}

A case study from Quesnel, British Columbia (Fig. 1) is used to illustrate how one community group is working towards sustainable community development. Located in the upper-Cariboo region of the central interior of British Columbia, Quesnel is a small resource-based town where the local economy is very much dependant upon the forestry industry. Approximately 35 percent of total employment, and 48 percent of basic sector employment, is directly within forestry (British Columbia 1995). Quesnel's economy does, however, have some diversity as there is agriculture (ranching), mining, and tourism activity as well.

The social and economic geography of the community is not unlike that of other, resource-based towns in Canada (Bowles 1992). While there are approximately similar numbers of females and males within the community, females are far over-represented in some social categories, such as lone parents (Table 1). Further, economic measures reflect some of the traditional patterns of limited female access to resourcebased employment. While approximately 60 percent of females aged 15 years and older are active participants in the paid workforce (compared to approximately 76 percent of males over 15 years of age), female earnings compare poorly to their male counterparts. In 1991, the average annual income for females in Quesnel was approximately $\$ 15000$. This was, however, only 48 percent of the average annual income for males. By comparison, females across Canada recorded about 59 percent of the 1991 average annual incomes of males. Looking just at full-time employment, females in Quesnel annually earn only about 56 percent of what males earn, and looking just at part-time and part-year employment, women in Quesnel earn only about 46 percent of what men earn. Again, these differences are grounded in the historical pattern of differential access for women to high paying resource-industry jobs.

\section{Quesnel Women's Resource Centre}

Not long ago, community development planning was generally limited to a select set of local decision-makers. This "topdown" approach has now largely been discarded in favour of more pluralist and "bottom-up" approaches. In order to implement successful sustainable community development initiatives, it is important to address the fundamental needs and concerns of women in the community. One result of changing the scope of community participation has been the inclusion of alternative voices in local debates. The Quesnel Women's Resource Centre is one such alternative voice. As a multi-goal organization, the Centre seeks to provide support to women by addressing unmet local needs. While a range of support, counselling, and shelter services are of key importance, the Centre is also interested in capacity building. By networking
Table 1. Quesnel, British Columbia, Background Data

\begin{tabular}{lcc}
\hline & Female & Male \\
\hline Total population & 4150 & 4035 \\
Lone parents & 345 & 70 \\
Participation rate & $59.9 \%$ & $75.6 \%$ \\
Average annual income & $\$ 14750$ & $\$ 30537$ \\
Average annual full-time employment income & $\$ 23025$ & $\$ 41096$ \\
Average annual part-time employment income & $\$ 9733$ & $\$ 21233$ \\
\hline
\end{tabular}

Source: Canada Census, 1991.

with entrepreneur development organizations, the Centre is providing local training opportunities to women. As well, the Centre employs women or offers volunteer work to provide functional work experience. The Centre's philosophy and practices reflect the capacity-building goals (at both the personal and community level) which underpin sustainable community development. By recognizing the value of female participation in the social and economic life of the community, the Centre is addressing local capacity building and participation challenges.

A paramount concern of the Centre is to provide counselling and services for women who have experienced abuse or have been in abusive relationships. In this regard, the Centre works closely in partnership with other agencies, including medical services providers, transition houses, the court system, and the police. Another concern of the Centre is to develop and provide self-esteem and self-assertiveness workshops and anger management workshops. These core activities are similar to the mandates of many such centres across Canada and provide a reminder of the social condition for many women in our communities.

The Centre is motivated by five specific goals (Fig. 2). These goals address specific challenges, such as violence against women or sexism. Others focus on the next step in capacity building at both the personal and "community" level by enhancing access to resources, education, and financial opportunity (selfempowerment). Funded by the provincial government's Ministry of Women's Equality and the federal government's Secretary of State, the Centre provides a safe, non-obtrusive, and "equal" place for women. The house is located in a residential neighbourhood close to the geographic centre of the community. The site was chosen to create a facility which is both welcoming and accessible, as well as removed from the impersonal office and commercial landscapes of the city's downtown core. The house and yard have been maintained much as any other residential home in the area so as to be non-threatening to potential clients.

The Centre functions with four paid staff as well as a large number of volunteers. Two professionally trained counsellors provide confidential and free counselling to individuals and/or groups of women. The focus of the counselling is to develop the motivations and skills for self-improvement from their current situation. There are also two support staff members who canvas community women regarding unmet needs and then develop appropriate courses and workshops to provide support on these issues. Some recent courses and workshops are in the areas of self-esteem, assertiveness, sign language, and parenting.

The social geography of Quesnel presents some challenges to female access to employment or educational upgrading. Shift work at the large forest products mills means that women with 
1) To provide women with access to resources, counselling and selfhelp programs that will assist them with life choices.

2) To actively address violence against women at all levels of the community.

3) To challenge sexism and all forms of discrimination against women at all levels of the community and help women achieve their rightful place in society.

4) To work towards the elimination of the feminization of poverty.

5) To enhance the status of women.

Fig. 2. Quesnel Women's Resource Centre Goals. Adapted from Quesnel Women's Resource Centre.

spouses or partners must adapt to a rotating cycle of shift work; as well, the seasonality of harvesting and silviculture work in the woods means that there are long periods of time when men are away from the community for extended periods of time. As a result, women who are married or with a partner find themselves in single-parent situations as there are long periods where they must do all of the child and household maintenance functions without the assistance from a spouse/ partner. While this uncertainty of schedules means that access for women with families to employment or educational courses is difficult, it also emphasizes the critical role they play in community sustainability. The substitution of paid labour for the unpaid domestic work of many of these women would be almost incalculable. At the very least, it could only be accomplished through a fundamental readjustment of wage levels in the community which would transfer the "costs" to the large firms.

The Centre has attempted to address, wherever possible, issues of barriers generated by the resource-community context. Courses and workshops have flexible schedules and are coordinated with major annual cycles in the forest industry. Advocacy for better services, and for increased flexibility in services such as daycare and after-school child care, has been undertaken. The Centre explicitly recognizes and validates the importance of women's non-paid domestic labour to personal, household, and community well-being. As opposed to a single focussed goal of, for example, getting women back into the paid labour force, the Centre adheres to an holistic model of social, economic, and personal empowerment of women. A wide range of directed and self-help initiatives are available to assist women with improving their skills and capacities in these areas so as to become more effective participants in, and contributors to, community development.

The Quesnel Women's Resource Centre has even developed ways of providing meaningful job experience in the context of the rather limited local work opportunities for women. One of the innovative aspects of the Centre's operations is that women may also volunteer time to assist with office and administration duties. Not only does this volunteer labour help to cut operating costs for the Centre, but the women can also learn or upgrade their office procedure and computer skills. Again, this is part of a broader vision of sustainable community development which centres around human capacity building, which in this case will give a foundation to women seeking to re-enter the paid labour force or start businesses of their own.

The Quesnel Women's Resource Centre is predominantly used by Caucasian women between the ages of 35 and 40 . These women are more likely to work in the home and hold an edu- cation level between grade twelve (completed high school) and one year of college. Some of the common concerns for these women include a lack of financial resources, the perpetual lack of work opportunities beyond minimum wage service sector employment, the lack of affordable child care, and the reality of non-nuclear families. Although these issues are not isolated to women in resource-based communities, they appear to be more prevalent here due to an historic understanding of work and home where norms of behaviour are encoded into the social and economic fabric.

One of the current challenges for the Centre derives directly from this local social geography fabric. There are presently a large number of women in the community whose ethnic background is South Asian. Community social service providers in Quesnel suggest that there may be a range of barriers to women using local services such as those at the Centre. While this problem may diminish over time as generational distance is added to family histories of recent immigration, that future is still years away and there is concern that many social and economic services needs are going unmet. While this type of issue can be both difficult and divisive (MartinezBrawley 1990), a number of outreach and community education initiatives have been supported by the Centre in an effort to establish a higher degree of trust and interaction with the many different constituencies of women within Quesnel.

The Quesnel Women's Resource Centre is characteristic of the third sector of society (neither public nor private), and can be said to be a part of the social economy. The Centre acknowledges gender disparity in the community. It provides emotional and social support for women and advocates for more community participation by women. The Centre's guiding principles address the two challenges of enhancing local human capacity and increasing local participation. Although the Centre is currently focussing on the immediate social needs of women in Quesnel, it is progressively expanding into other areas of personal development including entrepreneurial and business skills. Assistance and support of women in business is an area of future interest where the Centre, in conjunction with the Ministry of Small Business, Tourism and Culture, the local Chamber of Commerce, and the Community Futures Development Corporation, is seeking to expand opportunities for women in self-employment. For the Centre, women's membership in the community is recognized as a critical component of the economy.

\section{Discussion}

Female contributions to the development of the community through informal and unpaid labour are often marginalised or discounted. The economic sector is still associated with male space, and female participation within that space is made invisible. Yet it is precisely this female participation in the unpaid and informal sectors of the economy which support many aspects of community sustainability. The Quesnel Women's Resource Centre is challenging existing notions and is working towards a more holistic sense of collective responsibility for sustainable community development.

Women in resource-based towns must overcome systemic barriers not only as women, but as women in a male-dominated, resource-based economy and community. The Quesnel Women's Resource Centre is working to support women through enhancing their skills and capacities to participate in 
both the formal and informal sectors of the economy. The importance of the way in which the Centre is conceptualizing its services to address human capacity issues opens the way for these women to contribute to community development. In addressing pressing social needs, the Centre is playing catch-up with an economic and social context where women might otherwise continue to be invisible and their contribution to both the for$\mathrm{mal}$ and informal economies remain undervalued. This broader conceptualization of capacity building, together with the Centre's efforts to remove barriers to women's participation, is addressing key challenges to the implementation of sustainable development ideas in local communities.

\section{References}

Anderson, L., M. Conn, J. Donald and L. Kemp. 1994. Making Communities Work: Women and Community Economic Development. In B. Galaway and J. Hudson (eds.). Community Economic Development: Perspectives on Research and Policy. pp. 120-128. Thompson Educational Publishing, Toronto.

Bauen, R., B. Baker and K. Johnson. 1996. Sustainable Community Checklist (First Edition). Northwest Policy Centre, Graduate School of Public Affairs, University of Washington, Seattle.

Beckley, T.M. 1998. The (F)utility of "Community Sustainability" in an Inter-Dependent World. Ecoforestry, May: 34-40.

Bollman, R.D. and J.M. Bryden. (eds.). 1997. Rural Employment: An International Perspective. CAB International, New York. Bondi, L. 1990. Feminism, Postmodernism, and Geography: Space for Women? Antipode 22(2): 156-167.

Bowles, R.T. 1992. Single-Industry Resource Communities in Canada's North. In D.A. Hay and G.S. Basran (eds.). Rural Sociology in Canada. pp. 63-83. Oxford University Press, Toronto.

British Columbia. 1995. Quesnel Timber Supply Area: SocioEconomic Analysis. Ministry of Forests, Victoria.

Bryant, C.R. 1995. The Role of Local Actors in Transforming the Urban Fringe. Journal of Rural Studies 11(3): 255-267.

Bryden, J.M. (ed.) 1994. Towards Sustainable Rural Communities, University of Guelph, School of Rural Planning and Development, Guelph, Ontario.

Cofsky, S. and C. Bryant. 1994. Community Participation as a Differentiating Factor in the Local Development Process. Paper presented at a Development Study Group Session at the Canadian Association of Geographers Annual Meeting, Waterloo, Ontario.

Dominelli, L. 1995. Women in the Community: feminist principles and organising in community work. Community Development Journal 30(2): 133-143.

Galaway, B. and J. Hudson. (eds.) 1994. Community Economic Development: Perspectives on Research and Policy. Thompson Educational Publishing, Toronto.

Hak, G. 1989. The Socialist and Labourist Impulse in Small-Town British Columbia: Port Alberni and Prince George, 1911-33. Canadian Historical Review LXX(4): 519-542.

Halseth, G. 1993. Communities within Communities: Changing 'Residential' Areas at Cultus Lake, British Columbia. Journal of Rural Studies 9(2): 175-187.
Heald, S. 1991. Projects and Subjects: Women, the North, and job creation. In T.W. Dunk (ed.). Social Relations in Resource Hinterlands: Papers from the 27th Annual Meeting of the Western Association of Sociology and Anthropology, Thunder Bay, Ontario. pp. 105-121. Lakehead University Centre for Northern Studies, Northern and Regional Studies Series, vol. 1.

Kay, J. 1991. Landscapes of women and men: rethinking the regional historical geography of the United States and Canada. Journal of Historical Geography 17(4): 435-452.

Mackenzie, F. 1992. 'The worse it got, the more we laughed': A Discourse of Resistance Among Farmers of Eastern Ontario. Environment and Planning D: Society and Space 10: 691-713.

Marchak, P. 1983. Green Gold: The forest industry in British Columbia. University of British Columbia Press, Vancouver.

Marchak, P. 1989. History of a Resource Industry. In P.E. Roy (ed.). A History of British Columbia - Selected Readings. pp. 108-128. Copp Clark Pitman, Toronto.

Martinez-Brawley, E.E. 1990. Perspectives on the Small Community: Humanistic views for practitioners. National Association of Social Workers, Washington.

Maser, C. 1997. Sustainable Community Development: Principles and Concepts. St. Lucie Press, Delray Beach, Florida.

Mazey, M.E. and D.R. Lee. 1984. Her Space, Her Place: A Geography of Women. Association of American Geographers, Washington, DC.

McDowell, L. 1983. Towards and understanding of the gender divisions of urban space. Environment and Planning D: Society and Space 1: 59-72.

Mitchell, C. and F. Dahms. (eds.) 1997. Challenge and Opportunity: Managing Change in Canadian Towns and Villages. Department of Geography, University of Waterloo, Waterloo, Ontario.

Pearce, D., E. Barbier and A. Markandya. 1990. Sustainable Development. Economics and Environment in the Third World. Edward Elgar Publishing Limited, Hants, England and Brookfield, Vermont.

Perry, S.E. and M. Lewis. 1994. Reinventing the Local Economy: What 10 Canadian initiatives can teach us about building creative, inclusive, and sustainable communities. Centre for Community Enterprise, Vernon, British Columbia.

Pierce, J.T. 1992. Progress and the Biosphere: The dialectics of sustainable development. The Canadian Geographer 36(4): 306-320. Pratt, G. and S. Hanson. 1991. Time, Space, and the Occupational Segregation of Women: a Critique of Human Capital Theory. Geoforum 22(2): 149-157.

Reed, M. 1997. Seeing Trees: Engendering environmental and land use planning. The Canadian Geographer 41(4): 398-414.

Reed, M. and O. Slaymaker. 1993. Ethics and sustainability: A preliminary perspective. Environment and Planning A 25: 723-739.

Shaffer, R. and G.F. Summers. 1989. Community Economic Development. In J.A. Christenson and J.W. Robinson Jr. (eds.). Community Development in Perspective. pp. 173-195. Iowa State University Press, Ames, Iowa.

World Commission on Environment and Development. 1987. Our Common Future. Oxford University Press, New York. 